\title{
Current Situation of Egyptian Cotton: Econometrics Study Using ARDL Model
}

\author{
Yosri Nasr Ahmed ${ }^{1,2} \&$ Huang Delin ${ }^{2}$ \\ ${ }^{1}$ Institute of Agricultural Economic and Development, Chinese Academy of Agriculture Science, Beijing, China \\ ${ }^{2}$ Faculty of Agriculture, Cairo University, Cairo, Egypt \\ Correspondence: Yosri Nasr Ahmed, Faculty of Agriculture, Cairo University, Cairo, Egypt. Tel: \\ 86-156-524-71380. E-mail: yousri_nasr@cu.edu.eg
}

Received: November 15, 2018

Accepted: May 9, 2019 Online Published: July 15, 2019

doi:10.5539/jas.v11n10p88

URL: https://doi.org/10.5539/jas.v11n10p88

\begin{abstract}
The Egyptian cotton crop have experienced challenges in recent years from a drop in the quantity produced and exported, to a decrease in cultivated areas, this have affected the production quantity and value of exports. This study aims to bridge the research gap by exploring the nexus between cultivated area of cotton in Egypt, Relative profitability (cotton-clover/rice-clover), export quantity of cotton, the export prices of Egyptian cotton and the export prices of American cotton (Pima). In order to clarify the relationship between the variables studied and the cultivated area of cotton, the research use time series data from 1980 to 2016, using the Autoregressive Distributed Lag (ARDL) bound test to the find the co-integration between the variables after checking the stationarity in chosen variables with different unit root tests e.g. Augmented Dickey-Fuller (ADF) and the Phillips-Perron (PP). The results show, significant factors that influence the cultivated area of cotton include Relative profitability (cotton-clover/rice-clover), export quantity of cotton in long run term. Which underscores the need for government support in agriculture, in particular, cotton crop support. The increasing trend of cotton cost with declining revenue and decreasing in exports quantity is the main cause of decreased cultivated area of Egyptian cotton. Research recommends that support should be given to cotton farmers, in the form of agricultural equipment or training in good agricultural practices or set a price for cotton guaranteeing a decent profit margin for the farmers. The government (policy makers) should improve the productivity of cotton with the purpose of reducing the total costs and increasing the degree of competitiveness of the Egyptian cotton. Some effective policy measures may include but not limited to, farmer training programs and providing better extension services that will led to the capacity development of farmers.
\end{abstract}

Keywords: Egyptian cotton, agriculture sector in Egypt, ARDL Model

\section{Introduction}

The agricultural sector is considered as one of the most important sectors in Egypt's economy, its contribution to the country's GDP is around 14\% (Dhehibi et al., 2016). This sector also accounts for about $25.8 \%$ of the total employment (Note 1). The agricultural sector is characterized by a cropping pattern based on many basic crops, e.g., cereals, sugar crops, fruits, vegetables, horticultural crops, fibers and oil crops. Cotton is one of the most important fiber crops, from which oils are extracted and also used in animal feed (Abou-Mandour \& Abdel Hakim 1995).

The evolution of Egyptian cotton sector started at the beginning18th century, when the ruler of Egypt promoted the crop to increase the nation's income, subsequently, the quality became legendary and trade-mark in the global market, establishing a global reputation. Egyptian cotton isn't considered as a mere crop; however, it is the history and future for the renaissance of modern Egypt (Karvy, 2009). White gold as the Egyptians calls it. (Salem, Atta, \& Ahmed, 2015). As well as, a robust competitor that exceeds the quality of global varieties due to its physical, technological properties and superior spinning consistency compared to last varieties that are identical in terms of length grade; This resulted due to the efforts submitted by all related sectors which include research, agricultural, production, marketing and industrial sectors. This continued until the mid-1980s (Ahmed, 2016). 
Where, Cotton was an important commodity in the Egyptian economy, it was also one of the most important sources of agricultural income. Cotton has been considered as the main cash crop for the Egyptian farmer and main export agricultural crops (Soliman \& Ewaida, 2005). It provides direct and indirect employment for one million workers, with invests 26 billion Egyptian pound in agriculture and its affiliated industries e.g. Textile industry, dyeing and garment industry. This crop is important for food security; Cotton seeds are used in feed industry and oil seed. As well as exported about $40 \%$ of its output. The size of the cotton crop fluctuated with prices and the world economy (Hatab, 2009), but really took off after the country's 1952 Revolution. This continued until the mid-1980s thereafter, over the past 38 years, the cotton cultivated area has undergone dramatic changes, witnessing a decline in domestic production and losing its export share in the global market despite that imports of cotton did not decrease at the global level but remained stable (Karvy, 2009). The aforesaid, thus indicates a setback in Egyptian cotton production.

Currently, cotton is cultivated in nine (9) Governorates in Egypt over a land area a little over 80.000 hectares with a percentage not exceeding $2 \%$ of agricultural land in 2016 . Also, about $89 \%$ of production is attributed to lower Egypt provinces (Delta), while production was only 1.36 million metric qantar (Economic Affairs Sector, Ministry of Agriculture 2016). Even though cotton crop bas faced difficulties after the economic liberalization policies in 1986. But now, Egyptian cotton faces more challenges (Abdel-Salam, Negm, \& Ardabb, 2009). Starting from agriculture, the industry and finally, the export challenges. At the agricultural level challenges, High production costs and low productivity, leading to a decline profit in Egyptian cotton per hectare. The existence of various alternative crops with higher returns which is preferable to producers like rice, corn, vegetables and others \& thus represent a major challenge to cotton planting (El Showeikh, 2015). Hence these are amongst the challenges facing cotton industry in this era of globalization and technological progress given the competitiveness of synthetic fibers, with lower prices and high-quality properties compared to cotton especially polyester which is preferable in manufacturing as it is characterized by specific properties that almost match the physical properties of cotton fibers (Abdi, Counselor, Specialist, \& Tate, 2018).

The recent technologies have increased the ability of using synthetic fibers to produce yarn and fabrics that can compete with cotton in prices; such yarns and fabrics are characterized by unique properties. Additionally, there has been a growing competition from American cotton (pima). These factors have heightened concerns with regards to the survival of Egyptian cotton. The major problems facing the development of cotton industry, which requires large finances to overcome the challenges and needs to develop the Egyptian spinning and weaving industry, are re-structuring of the Egyptian spinning and weaving companies, increasing their productive capacity through labor training, modernizing existing production lines and introducing new ones, on the export level, as well as the low global demand for long cotton (Abdi et al., 2018). The following variables have a direct or indirect effect on cultivated area of cotton (local price, total cotton costs, prices and costs of rice and clover) where the cotton and rice compete for the factor of the land, export quantity of cotton, export prices of Egyptian cotton and the export prices of American cotton (Pima).

Finally, Egyptian cotton crop industry have experienced difficulties in recent years from a clear decline in the quantity produced and exported, also given that the cultivated areas of cotton is decreasing, and the production quantity and value of exports decreased. Given the aforementioned, the aim of this study is to formulate and estimate the relationship of cointegration for the cotton crop in Egypt with a view to identifying principal factors that shape Farmers' response to cultivated areas of Egyptian cotton, and to set a clear path for the state to reinforce the cotton industry. To achieve the research objective the rest of the research is organized as follows. In the subsequent section we present a description of data and their sources. Section three deals with the methodology used in the study and model Specification. Section four presents the results and discussion. The final section presents the conclusions and recommendations.

\section{Description of Data}

This study employed time series data on the cultivated area of cotton (1000 hectare), relative profitability (cotton-clover/rice-clover), export quantity of cotton (thousand tons), the export prices of Egyptian cotton and the export prices of American cotton (Pima) extending over the period from 1980 to 2016. The data were sourced from Economic Affairs Sector, Ministry of Agriculture and Land Reclamation, Egypt, Annual Data. Global prices were collected from UNCTD (Note 2) and Food and Agriculture Organization, FAO.

Table 1 presents the summary statistics of the variables. Each variable included 37 observations of time series data from (1980-2016). All variables show high variability during the study period, since all of them have a high standard deviation in relation to its average. The average cultivated area of cotton in Egypt is about 261.000 ha, over the period of 1980-2016, with a maximum area of 509 thousand hectares in 1980, began to decline to 85 
thousand hectares in 2016. Yield has an average of 16 (qantar/ha), the yield is between a maximum quantity of 19 and a minimum quantity of 12 (qantar/ha), indicating that there is no technological role to increase the yield. while the Production mean in Egypt is 4.205 million qantar, this is due to the high cultivated area with relatively constant yield. Table 1 also reports that the average of the Export quantity is 1.845 million qantar.

Table 1. Summary statistics

\begin{tabular}{llllllll}
\hline & $\begin{array}{l}\text { Cultivated area } \\
(1000 \mathrm{hA})\end{array}$ & $\begin{array}{l}\text { Yield } \\
(\text { Qantar/ha) }\end{array}$ & $\begin{array}{l}\text { Production } \\
(1000 \text { Qantar })\end{array}$ & $\begin{array}{l}\text { Revenue } \\
(\text { LE/ha })\end{array}$ & $\begin{array}{l}\text { Total cost } \\
(\text { LE/ha })\end{array}$ & $\begin{array}{l}\text { Export Quantity } \\
(1000 \text { Qantar })\end{array}$ & $\begin{array}{l}\text { Export Value } \\
(1000 \text { US\$) }\end{array}$ \\
\hline Mean & 261 & 16 & 4205 & 8332 & 5222 & 1843 & 232875 \\
Standard Deviation & 119 & 2 & 2133 & 6174 & 3940 & 1216 & 140641 \\
Minimum & 85 & 12 & 1361 & 870 & 578 & 260 & 43586 \\
Maximum & 509 & 19 & 8962 & 21687 & 13451 & 4178 & 485949 \\
\hline
\end{tabular}

Note. Qantar $=52.5 \mathrm{~kg}$ of cotton.

Source: Authors' compilation.

\section{Methodology and Model Specification}

This research used the autoregressive distributed lag (ARDL) bound testing procedure to examine possible the cointegration (long-run) relationships among the cultivated area of Egyptian cotton and each of relative profitability (cotton-clover/rice-clover), have been used to avoid econometric problems as they reflect both the price and costs of cotton and competing crops, e.g., rice and export quantity of cotton, the export prices of Egyptian cotton and the export prices of American cotton. Analysis of the effect of these variables on the cultivated area of Egyptian cotton in the long and short term. The pound test is essentially computed based on a predestined error correction version of autoregressive distributed lag (ARDL) model, by Ordinary Least Square (OLS) estimator (Pesaran, Shin, \& Smith, 2001).

The bound testing procedure was selected rather than other methods to co-integration, because of the following:

1) Johansen cointegration approach require the variables under study must be integrated of the same order. But the bounds test procedure does not require that the variables under study must be integrated of the same order unlike other techniques. It is applicable irrespective of whether the regressors in the model are I(0), I(1).

2) The bounds testing approach is convenient for small sample data, unlike the other cointegration approach. Its suitability for small sample research is noting given that the sample duration of this research is limited (37 years).

3) The bounds test is an unpretentious approach because it allows the co-integration relationship to be estimated by OLS, once the lags of the variables are identified unlike another multivariate co-integration approach.

4) ARDL Model provides useful information on long-run and short-run elasticities. It is also shown if the expected sign of every variable is consistent with the theory or not (M. H. Pesaran \& B. Pesaran, 1997; Pesaran et al., 2001).

5) An F-test of the joint significance of the coefficients of the lags levels of the variables was used to test the hypothesis of no cointegration between the variables versus the presence of cointegration between the variables. The null hypothesis of no cointegration between the cultivated area of Egyptian cotton and each of Relative profitability (cotton-clover/rice-clover), export quantity of cotton, the export prices of Egyptian cotton and the export prices of American cotton was given as:

Ho: $\varphi_{1}=\varphi_{2}=\varphi_{3}=\varphi_{4}=\varphi_{5}$

The alternative hypothesis was given as,

$\mathrm{H}_{1}: \varphi_{1} \neq \varphi_{2} \neq \varphi_{3} \neq \varphi_{4} \neq \varphi_{5}$

The F-test has a nonstandard distribution irrespective of whether the variables are $1_{(0)}$ or $1_{(1)}$. (Pesaran et al., 2001). It was giving two sets of adjusted critical values that provide the upper and lower bounds used for inference. One set assumes that all variables are $1_{(0)}$ and the other assumes that they are all $1_{(1)}$. When the computed F-statistics is above the upper bound critical value, then the null hypothesis of no co-integration is rejected. Insomuch as it falls below the lower bound, then the null cannot be rejected. Finally, if it falls between 
the upper and lower bound, thereafter the result would be inconclusive. The optimal lag Periods for ARDL model was determined according to the Akaike Information Criterion (AIC).

The relationship between the cultivated area of cotton, relative profitability (cotton-clover), export quantity of cotton, the export prices of Egyptian cotton and the export prices of American cotton (Pima) is expressed as:

$$
\mathrm{Y}=f(\mathrm{X} 1, \mathrm{X} 2, \mathrm{X} 3, \mathrm{X} 4)
$$

Where,

Y: refers to cultivated area of cotton (1000 hectare); X1: refers to Relative profitability (cotton-clover/rice-clover); X2: refers to export quantity of cotton (thousand tons); X3: refers to the export prices of Egyptian cotton; X4: refers to the export prices of American cotton (Pima).

The cultivated area (Egyptian cotton) is affected by the relative profitability (for the cotton-clover cycle), the quantity and the export price of Egyptian cotton, because its main purpose is to export. Also, there are a negative relationship between the cultivated area (Egyptian cotton) and US cotton exports (the strongest competitor for Egyptian cotton).

Following (Pesaran, Shin, \& Smith 2001) the ARDL model specification of Equation (1) is expressed as unrestricted error correction model (UECM) to test for co-integration among the variables under studying:

$$
\begin{aligned}
& \Delta \cdot \operatorname{LnY} \cdot \mathrm{t}=\varphi 0+\sum_{\mathrm{n}=1}^{\mathrm{p}} \varphi 1 \cdot \Delta \cdot \operatorname{LnY} \cdot \mathrm{t}-\mathrm{i}+\sum_{\mathrm{n}=0}^{\mathrm{p}} \varphi 2 \cdot \Delta \cdot \operatorname{LnX} 1 \cdot \mathrm{t}-\mathrm{i}+\sum_{\mathrm{n}=0}^{\mathrm{p}} \varphi 3 \cdot \Delta \cdot \operatorname{LnX} 2 \cdot \mathrm{t}-\mathrm{i}+\sum_{\mathrm{n}=0}^{\mathrm{p}} \varphi 4 \cdot \Delta \cdot \operatorname{LnX} 3 \cdot \mathrm{t}-\mathrm{i} \\
& +\sum_{\mathrm{n}=0}^{\mathrm{p}} \varphi 5 \cdot \Delta \cdot \operatorname{LnX} 4 \cdot \mathrm{t}-\mathrm{I}+\beta 1 \cdot \operatorname{LnY} \cdot \mathrm{t}-\mathrm{I}+\beta 2 \cdot \operatorname{LnX} 1 \cdot \mathrm{t}-1+\beta 3 \cdot \operatorname{LnX} 2 \cdot \mathrm{t}-1+\beta 4 \cdot \operatorname{LnX} \cdot \mathrm{t}-1+\beta 5 \cdot \operatorname{LnX} 4 \cdot \mathrm{t}-1+\mu \mathrm{t}
\end{aligned}
$$

Once cointegration is determined, the long run relationship is estimated bring into play the ARDL model specified as:

$$
\mathrm{Ln} \cdot \mathrm{Yt}=\varphi 0+\beta 1 \cdot \operatorname{LnY} \cdot \mathrm{t}-1+\beta 2 \cdot \operatorname{LnX} 1 \cdot \mathrm{t}-1+\beta 3 \cdot \operatorname{LnX} \cdot \mathrm{t}-1+\beta 4 \cdot \operatorname{LnX} 3 \cdot \mathrm{t}-1+\beta 5 \cdot \operatorname{LnX} 4 \cdot \mathrm{t}-1+\mu \mathrm{t}
$$

The short run dynamic relationship is estimated bring into play by error correction model (ECM) specified as:

$$
\begin{aligned}
\Delta \cdot \operatorname{LnY} \cdot \mathrm{t} & =\varphi 0+\sum_{\mathrm{n}=1}^{\mathrm{p}} \varphi 1 \cdot \Delta \cdot \operatorname{LnY} \cdot \mathrm{t}-\mathrm{i}+\sum_{\mathrm{n}=0}^{\mathrm{p}} \varphi 2 \cdot \Delta \cdot \operatorname{LnX} 1 \cdot \mathrm{t}-\mathrm{i}+\sum_{\mathrm{n}=0}^{\mathrm{p}} \varphi 3 \cdot \Delta \cdot \operatorname{LnX} 2 \cdot \mathrm{t}-\mathrm{i} \\
& +\sum_{\mathrm{n}=0}^{\mathrm{p}} \varphi 4 \cdot \Delta \cdot \operatorname{LnX} 3 \cdot \mathrm{t}-\mathrm{i}+\sum_{\mathrm{n}=0}^{\mathrm{p}} \varphi 5 \cdot \Delta \cdot \operatorname{LnX} 4 \cdot \mathrm{t}-\mathrm{I}+\delta \mathrm{ecm} \cdot \mathrm{t}-1+\mu \mathrm{t}
\end{aligned}
$$

Where,

Y: refers to the cultivate area of cotton (hectare); X1: refers to Relative profitability (cotton-clover); X2: refers to export quantity of cotton (thousand tons); X3: refers to the export prices of Egyptian cotton; X4: the export prices of American cotton (Pima); $\varphi 0$ : refers to the constant term; $\mu$ t: refers to the white noise; $\varphi 1-\varphi 5$ : refers to the short run elasticities (coefficients of the first-differenced explanatory variables); $\beta 1-\beta 5$ : refers to the long run elasticities (coefficients of the explanatory variables); ecm.t-1: refers to the error correction term lagged for one period; $\delta$ : speed of adjustment; $\Delta$ : first difference operator; Ln: natural logarithm; $\mathrm{p}$ : lag length.

The analysis of the data was carried out using Eviews 10.

\section{Results and Discussion}

This section focused on the results using basic econometric techniques, e.g., stationarity of data, auto regressive distributed lags model and bound testing procedure (ARDL). The research used the Augmented Dickey-Fuller (ADF) and the Phillips-Perron (PP) tests the order of integration for each variable under consideration. This study starts with an analysis to determine the order of integration, if the variables in levels order or in first differences or in second differences. This step is important to determine whether the variables integrated of order zero I( $(0)$, one $\mathrm{I}(1)$ or two I( 2$)$.

Granger and Newbold and Phillips explained that stationary data should be used, when the research uses non-stationary data this can lead to spurious regression results. Therefore the first step was to use ADF and PP unit root test to estimate the order of integration of the variables and tests for the presence of a unit root-mentioned earlier. Although the bounds testing does not require the pre-testing of each variable in the model for unit roots owing to its appropriateness irrespective of whether the regressors are $\mathrm{I}(0), \mathrm{I}(1)$ or mutually cointegrated, but we need to, the application of unit root tests prior to using the ARDL Model, might still be necessary in order to ensure that the regress and is integrated of $\mathrm{I}(1)$ and $\mathrm{I}(0)$ or the variables are integrated of order 2 . Where the model can only be used if the variables are cointegrated from order $\mathrm{I}(0)$ and $\mathrm{I}(1)$ or mutually cointegrated. Tables 2 and 3 show the unit root analysis using ADF and PP, the results from both tests all variables (cultivated area of cotton, the export quantity of cotton, the export prices of Egyptian cotton and the 
export prices of American cotton) are Non-stationary except relative profitability, when all variables are stationary at the first difference. This means that, all of (cultivated area of cotton, the export quantity of cotton, the export prices of Egyptian cotton and the export prices of American cotton) the variables are integrated of order I(1) and the relative profitability is integrated of order I(0). Especially, the dependent variable is integrated at the first difference. Hence, the can proceed using the ARDL model (Granger \& Newbold, 1974) and (Phillips, 1986).

Table 2. The results of ADF test

\begin{tabular}{|c|c|c|c|c|c|c|}
\hline \multirow{2}{*}{ Constant \& Trend } & \multirow{2}{*}{ ADF Statistics } & \multicolumn{5}{|c|}{ At level } \\
\hline & & $\mathrm{Y}$ & $\mathrm{X} 1$ & $\mathrm{X} 2$ & $\mathrm{X} 3$ & $\mathrm{X} 4$ \\
\hline \multirow{3}{*}{ With Constant } & t-Statistic & -1.31 & -4.44 & -3.08 & -2.31 & -3.40 \\
\hline & Prob. & 0.61 & 0.00 & 0.03 & 0.17 & 0.02 \\
\hline & & NO & $* * *$ & $* *$ & NO & $* *$ \\
\hline \multirow{3}{*}{ With Constant \& Trend } & t-Statistic & -4.61 & -4.67 & -3.29 & -3.17 & -3.45 \\
\hline & Prob. & 0.00 & 0.00 & 0.08 & 0.10 & 0.06 \\
\hline & & $* * *$ & $* * *$ & $*$ & NO & $*$ \\
\hline \multirow{3}{*}{ Without Constant \& Trend } & t-Statistic & -2.61 & -1.64 & -2.03 & -0.67 & -0.87 \\
\hline & Prob. & 0.01 & 0.09 & 0.04 & 0.42 & 0.32 \\
\hline & & $* *$ & * & $* *$ & NO & NO \\
\hline & & \multicolumn{5}{|c|}{ At 1 difference } \\
\hline \multirow{3}{*}{ With Constant } & \multirow{3}{*}{$\begin{array}{l}\text { t-Statistic } \\
\text { Prob. }\end{array}$} & -7.43 & -5.84 & -6.47 & -4.88 & -6.86 \\
\hline & & 0.00 & 0.00 & 0.00 & 0.00 & 0.00 \\
\hline & & $* * *$ & $* * *$ & $* * *$ & $* * *$ & $* * *$ \\
\hline \multirow{3}{*}{ With Constant \& Trend } & \multirow{3}{*}{$\begin{array}{l}\text { t-Statistic } \\
\text { Prob. }\end{array}$} & -7.35 & -5.74 & -6.52 & -4.81 & -6.77 \\
\hline & & 0.00 & 0.00 & 0.00 & 0.00 & 0.00 \\
\hline & & $* * *$ & $* * *$ & $* * *$ & $* * *$ & $* * *$ \\
\hline \multirow{3}{*}{ Without Constant \& Trend } & t-Statistic & -6.69 & -8.76 & -6.38 & -4.95 & -6.96 \\
\hline & \multirow[t]{2}{*}{ Prob. } & 0.00 & 0.00 & 0.00 & 0.00 & 0.00 \\
\hline & & $* * *$ & $* * *$ & $* * *$ & $* * *$ & $* * *$ \\
\hline
\end{tabular}

Note. $(*)$ Significant at the $10 \% ;(* *)$ Significant at the $5 \% ;(* * *)$ Significant at the $1 \%$; (NO) Not Significant.

*Mackinnon (1996) one sided P-Valuse.

Source: Author's computation using Eviews 10. 
Table 3. Result of phillips-perron unit root test

\begin{tabular}{|c|c|c|c|c|c|c|}
\hline \multirow{2}{*}{ Constant \& Trend } & \multirow{2}{*}{ PP Statistics } & \multicolumn{5}{|c|}{ At level } \\
\hline & & $\mathrm{Y}$ & $\mathrm{X} 1$ & $\mathrm{X} 2$ & $\mathrm{X} 3$ & $\mathrm{X} 4$ \\
\hline \multirow{3}{*}{ With Constant } & t-Statistic & -1.66 & -2.93 & -2.93 & -2.315 & -3.43 \\
\hline & \multirow[t]{2}{*}{ Prob. } & 0.44 & 0.00 & 0.05 & 0.01 & 0.01 \\
\hline & & No & $* * *$ & $*$ & $*$ & $* * *$ \\
\hline \multirow{3}{*}{ With Constant \& Trend } & t-Statistic & -4.51 & -4.68 & -3.25 & -2.33 & -3.45 \\
\hline & \multirow{2}{*}{ Prob. } & 0.005 & 0.003 & 0.09 & 0.41 & 0.06 \\
\hline & & $* * *$ & $* * *$ & $*$ & NO & $*$ \\
\hline \multirow{3}{*}{ Without Constant \& Trend } & t-Statistic & -2.98 & -1.403 & -1.65 & -0.55 & -0.73 \\
\hline & \multirow[t]{2}{*}{ Prob. } & 0.003 & 0.14 & 0.09 & 0.49 & 0.39 \\
\hline & & $* * *$ & NO & $*$ & NO & NO \\
\hline \multirow{4}{*}{ With Constant } & \multirow{4}{*}{$\begin{array}{l}\text { t-Statistic } \\
\text { Prob. }\end{array}$} & \multicolumn{3}{|c|}{ At 1 difference } & & \\
\hline & & -15.62 & -25.1 & -9.97 & -5.44 & -8.15 \\
\hline & & 0.00 & 0.00 & 0.00 & 0.00 & 0.00 \\
\hline & & $* * *$ & $* * *$ & $* * *$ & $* * *$ & $* * *$ \\
\hline \multirow{3}{*}{ With Constant \& Trend } & \multirow{3}{*}{$\begin{array}{l}\text { t-Statistic } \\
\text { Prob. }\end{array}$} & -16.45 & -24.39 & -10.16 & -5.26 & -8.15 \\
\hline & & 0.00 & 0.00 & 0.00 & 0.00 & 0.00 \\
\hline & & $* * *$ & $* * *$ & $* * *$ & $* * *$ & $* * *$ \\
\hline \multirow{3}{*}{ Without Constant \& Trend } & t-Statistic & -7.34 & -19.67 & 9.34 & -5.56 & -8.34 \\
\hline & \multirow{2}{*}{ Prob. } & 0.00 & 0.00 & 0.00 & 0.00 & 0.00 \\
\hline & & $* * *$ & $* * *$ & $* * *$ & $* * *$ & $* * *$ \\
\hline
\end{tabular}

Note. (*) Significant at the 10\%; (**) Significant at the 5\%; (**) Significant at the 1\%; (NO) Not Significant.

* Mackinnon (1996) one sided P-Valuse.

Source: Author's computation using Eviews 10.

After completing the ADF and PP tests, to check the order of integration for each variable, the study proceed to generate the F-statistics as shown in Table 4 below. It can be seen that when cotton area is taken as a dependent variable and relative profitability, export quantity of cotton, the export prices of Egyptian cotton and the export prices of American cotton as independent variables. The null hypothesis shows a non-existence of a long-run relationship, while the alternative hypothesis shows the existence of a cointegrating relationship. It must be noted, that $\mathrm{F}$-statistic is 4.46 and is greater than all the upper bounds at $1 \%, 2.5 \%, 5 \%$ and $10 \%$ significance levels. The paper therefore rejected the null hypothesis and accept the alternative hypothesis. So, we decided that there exists a long run relationship between the independent variables and the dependent variable.

Table 4. Result of F-Bounds test

\begin{tabular}{lllll}
\hline Test Statistic & Value & Signif. & $\mathrm{I}(0)$ & $\mathrm{I}(1)$ \\
\hline F-statistic & 4.464044 & $10 \%$ & 2.2 & 3.09 \\
& & $5 \%$ & 2.56 & 3.49 \\
& & $2.5 \%$ & 2.88 & 3.87 \\
& & $1 \%$ & 3.29 & 4.37 \\
\hline
\end{tabular}

Note. $k$ is the number of regressors.

Source: Author's computation using Eviews 10.

Now, that we confirmed the existence of cointegration between the variables, we proceeded with the estimation of the appropriate ARDL model for the all variable. The optimal ARDL $(4,1,3,0,2)$ specification has been chosen based on the Schwarz Bayesian Criterion and as presented in Table 5 below. 
Table 5. Autoregressive Distributed Lag Estimates. ARDL (4, 1, 3, 0, 2) selected

\begin{tabular}{lllll}
\hline Variable & Coefficient & Std. Error & t-Statistic & Prob. $^{*}$ \\
\hline Y(-1) & 0.038944 & 0.233470 & 0.166807 & 0.8694 \\
Y(-2) & -0.054193 & 0.233287 & -0.232304 & 0.8189 \\
Y(-3) & 0.258228 & 0.179675 & 1.437192 & 0.1678 \\
Y(-4) & 0.526734 & 0.152117 & 3.462681 & 0.0028 \\
X1 & 62.24759 & 24.86485 & 2.503437 & 0.0221 \\
X1(-1) & 69.09502 & 26.26324 & 2.630864 & 0.0170 \\
X2 & 0.222719 & 0.046434 & 4.796471 & 0.0001 \\
X2(-1) & 0.007849 & 0.063034 & 0.124514 & 0.9023 \\
X2(-2) & 0.014123 & 0.061594 & 0.229295 & 0.8212 \\
X2(-3) & -0.132734 & 0.061374 & -2.162722 & 0.0443 \\
X3 & 0.418032 & 0.268751 & 1.555462 & 0.1372 \\
X4 & -0.965101 & 0.526953 & -1.831475 & 0.0836 \\
X4(-1) & 0.873825 & 0.451371 & 1.935937 & 0.0687 \\
X4(-2) & 0.561237 & 0.401980 & 1.396182 & 0.1796 \\
C & -201.2021 & 64.89011 & -3.100658 & 0.0062 \\
R-squared & 0.941587 & & Mean dependent var. & 236.2201 \\
Adjusted R-squared & 0.896155 & & S.D. dependent var. & 101.3508 \\
S.E. of regression & 32.66033 & & Akaike info criterion & 10.11315 \\
Sum squared resid & 19200.55 & Schwarz criterion & 10.79339 \\
Log likehood & -151.8671 & Hannan-Quinn criterion & 10.34203 \\
F-statistic & 20.72504 & Durbin-Watson stat. & 1.921606 \\
Prob(F-statistic) & 0.000000 & & \\
\hline
\end{tabular}

Note. p-values and any subsequent tests do not account for model.

Source: Author's computation using Eviews 10.

Table 6 displays the long-run parameters of the ARDL model. The estimates shows a strong causal effects (at a smaller than the 5\% level of statistical significance) directed from X1 and X2 towards $\mathrm{Y}$, When X3 and X4 are not-significant.

Table 6. Estimated long run coefficients using the ARDL approach. ARDL $(4,1,3,0,2)$ selected

\begin{tabular}{|c|c|c|c|c|}
\hline Variable & Coefficient & Std. Error & t-Statistic & Prob. \\
\hline $\mathrm{X} 4$ & 2.040763 & 2.749741 & 0.742166 & 0.4676 \\
\hline $\mathrm{X} 3$ & 1.815264 & 0.983630 & 1.845474 & 0.0815 \\
\hline $\mathrm{X} 2$ & 0.486162 & 0.196551 & 2.473466 & 0.0236 \\
\hline $\mathrm{X} 1$ & 570.3428 & 217.0695 & 2.627467 & 0.0171 \\
\hline $\mathrm{C}$ & -873.7007 & 439.0278 & -1.990081 & 0.0620 \\
\hline \multicolumn{5}{|c|}{$\mathrm{EC}=\mathrm{Y}-(2.0408 \cdot \mathrm{X} 4+1.8153 \cdot \mathrm{X} 3+0.4862 \cdot \mathrm{X} 2+570.3428 \cdot \mathrm{X} 1-873.7007)$} \\
\hline
\end{tabular}

Source: Author's computation using Eviews 10.

Following the estimation of F-Bounds Test, we advance our analysis by estimating Error Correction Model (ECM), In order to reach a balance in the long term. The results of ECM are presented in Table 7 below. As shown ECT are statistically significant with negative signs. With reference to the Granger Representation Theorem (Engle \& Granger, 1987; Granger, 1983), per se refers to the existence of a long-run relationship between the variables, meaning there exist a valid error-correction representation and vice versa. But the main purpose of ECM is to clarify the speed of adjustment of any deviation towards in the long-run equilibrium. In particular, the value of ECT (-0.23) for the Egyptian cotton area equation indicates that about $23 \%$ of the previous year's variation between the actual and equilibrium value of cotton area in Egypt is corrected for each year. Although our result is consistent with the theoretical prediction adjustment and adaptive expectation models as mentioned at (Askari \& Cummings, 1977; Nerlove, 1958) which demonstrated that output will adjust but not fully. Furthermore, the diagnostic tests rejected some problems in econometric side. The test for ARCH 
test rejects heteroskedasticity in the disturbance term at 5\% level of significance (Table 8 ). In additional to, the LM test result indicates that there exists no serial correlation in the residuals.

Table 7. Short-run dynamic error correction representation for ARDL Model (4, 1,3,0,2)

\begin{tabular}{|c|c|c|c|c|}
\hline Variable & Coefficient & Std. Error & t-Statistic & Prob. \\
\hline $\mathrm{D}(\mathrm{Y}(-1))$ & -0.730768 & 0.180717 & -4.043707 & 0.0008 \\
\hline $\mathrm{D}(\mathrm{Y}(-2))$ & -0.784962 & 0.167207 & -4.694545 & 0.0002 \\
\hline $\mathrm{D}(\mathrm{Y}(-3))$ & -0.526734 & 0.125616 & -4.193215 & 0.0005 \\
\hline $\mathrm{D}(\mathrm{X} 1)$ & 62.24759 & 18.98172 & 3.279344 & 0.0042 \\
\hline $\mathrm{D}(\mathrm{X} 2)$ & 0.222719 & 0.034462 & 6.462763 & 0.0000 \\
\hline $\mathrm{D}(\mathrm{X} 2(-1))$ & 0.118611 & 0.053500 & 2.217025 & 0.0397 \\
\hline $\mathrm{D}(\mathrm{X} 2(-2))$ & 0.132734 & 0.048429 & 2.740802 & 0.0134 \\
\hline $\mathrm{D}(\mathrm{X} 4)$ & -0.965101 & 0.346103 & -2.788479 & 0.0121 \\
\hline $\mathrm{D}(\mathrm{X} 4(-1))$ & -0.561237 & 0.322996 & -1.737598 & 0.0994 \\
\hline$(\mathrm{ECM})$ CointEq $(-1)^{*}$ & -0.230287 & 0.039364 & -5.850157 & 0.0000 \\
\hline
\end{tabular}

Note. Adjusted R-squared 75\%. DW $=1.92 . *$ p-value incompatible with t-Bounds distribution.

Source: Author's computation using Eviews 10.

Table 8. Heteroskedasticity test: ARCH

\begin{tabular}{ll|ll}
\hline F-statistic & 0.499 & Prob. F(1.30) & 0.485 \\
Obs* R-squared & 0.524 & Prob.Chi-Square(1) & 0.469 \\
\hline
\end{tabular}

Source: Author's computation using Eviews 10.

The research estimates cumulative sum of square (CUSUMQ) and the cumulative sum (CUSUM) plots from - within 5\% significance level - a recursive estimation of the model is shown in Figures 1 and 2 to show the data stability. This indicate stability in the coefficients over the sample period as the plot of the CUSUM and CUSUMSQ statistic fall inside the critical bands of the 5\% confidence interval of parameter stability.

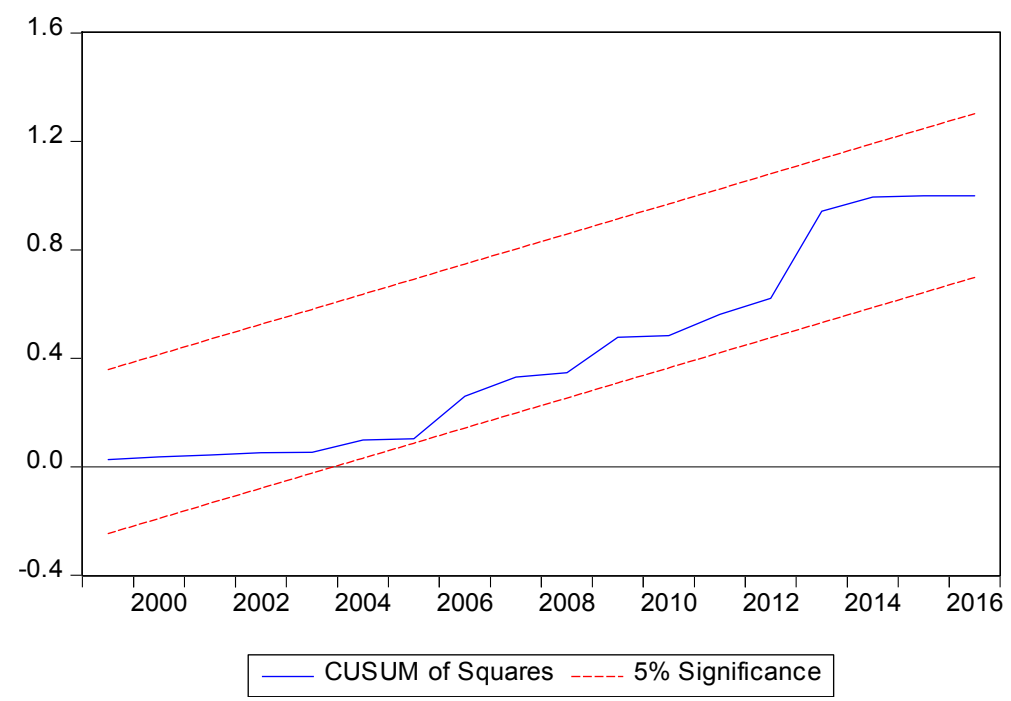

Figure 1. Plot of cumulative sum of squares of recursive residuals 


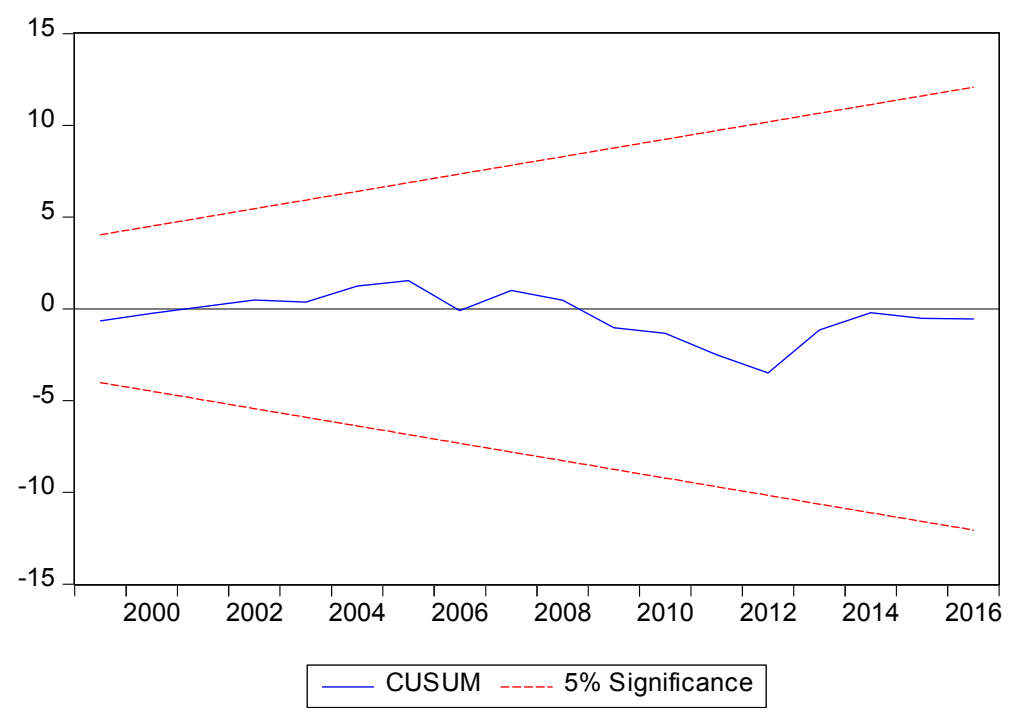

Figure 2. Plot of cumulative sum of recursive residuals

\section{Conclusion}

The agriculture sector is considered as one of the most important sectors in Egypt's economy, its contribution to the country's GDP is around $14 \%$ as stated earlier. This sector also accounts for about a quarter $(25.8 \%)$ of the total employment. Cotton was one of the most important agricultural crops in Egypt. Egyptian cotton is not considered as a mere crop, but it is seen as a complete sector. hence it is popularly referred to as a "white gold" by Egyptians. Cotton was an important commodity in the Egyptian economy, it was also one of the most important sources of agricultural income. Cotton has been considered as the main cash crop for the Egyptian farmer and main most important export agricultural crop. The cotton sector plays a vital role in providing direct and indirect employment in the agricultural and agriculture affiliated industries e.g. Textile industry, dyeing and garment industry. It serves food security; Cotton seeds are used in feed industry and oilseed. Currently, cotton is cultivated in 9 Governorates in Egypt over a land of about 80.000 hectares with a percentage not exceeding 2\% of agricultural land in 2016. About $89 \%$ of production is attributed to lower Egypt province (Delta). While production was only 1.36 million metric qantar. Even though such cotton crop bas faced difficulties after the economic liberalization policies in 1986. Recently, Egyptian cotton faces more challenge, starting from agriculture, the industry and finally, the export challenges. The agriculture and market challenges of Egyptian Cotton are, high production costs and low productivity, leading to a decline profit in Egyptian cotton per hectare. Which led to a decrease in the cultivated areas of cotton, and the production quantity, thereby resulting to the value of exports decline. Accordingly, the aim of this study is to formulate and estimate the relationship of cointegration for the cotton crop in Egypt with a view to identifying principal factors that shape Farmers' response to cultivated area of Egyptian cotton, and to set a clear path for the state to reinforce the cotton crop. To achieve this aim the study used annual data covering the period 1980-2016 for cultivated area of cotton in Egypt, relative profitability (cotton-clover/rice-clover), export quantity of cotton, the export prices of Egyptian cotton and the export prices of American cotton (Pima). The tests for co-integration revealed (ADF and PP) that variables under consideration are integration from order (i.e., $\mathrm{I}(0)$ and $\mathrm{I}(1)$ ), thus illustrating that an ARDL technique was appropriate for the study. The empirical results based on the ARDL Model show that the cultivated area of cotton in Egypt is co-integrated with relative profitability (cotton-clover/rice-clover), export quantity of cotton. The optimal ARDL $(4,1,3,0,2)$ specification have been chosen based on the Schwarz Bayesian Criterion, with four lag (years) for cultivated area and one lag to relative profitability (cotton-clover/rice-clover) and this is very logical for Egyptian agriculture. As far as the short run analysis is concern, the study demonstrates that about $23 \%$ of variation in cultivated area of cotton in Egypt is corrected within a year. The increasing trend of cotton cost with decreasing revenue and decreasing in exports quantity is the main cause of decreased cultivated area of Egyptian cotton. This is what the results of this research show. Therefore, the study recommends that the government (policy makers) should improve the productivity of cotton with the purpose of reducing the total costs and increasing the degree of competitiveness of the Egyptian cotton. Some effective policy measures e.g. capacity building for farmer through training programs and provision of better extension services that will yield increase productivity and competitive of the sector. 


\section{References}

Abdel-Salam, M. E., Negm, M., \& Ardabb, C. S. (2009). The Egyptian cotton, current constraints and future opportunities. Textile Industries Holding Co., Modern Press, Alexandria, Egypt.

Abdi, A., Counselor, A. M., Specialist, A., \& Tate, B. (2018). Egypt 2018 Cotton and Products Annual Egyptian Cotton on the Rise.

Abou-Mandour, M., \& Abdel Hakim, T. (1995). Egyptian Agriculture: Its Characteristics, Historical Development and Current Challenges. Egyptian Agriculture Profile, 13, 3-13.

Ahmed, Y. (2015). Estimating the Egyptian cotton production indicators through 1980-2013 (Master thesis, Cairo University, Egypt).

Ahmed, Y. (2016). The Egyptian Cotton: The Present And The Future Situation. Agric. Econom. and Social Sci., 6(10), 1611-1624.

Askari, H., \& Cummings, J. T. (1977). Estimating agricultural supply response with the Nerlove model: A survey. International Economic Review, 18(2), 257-292. https://doi.org/10.2307/2525749

Dhehibi, B., Ibrahim Ali El-Shahat, A. A., Frija, A., \& Hassan, A.-A. (2016). Growth in Total Factor Productivity in the Egyptian Agriculture Sector: Growth Accounting and Econometric Assessments of Sources of Growth. Sustainable Agriculture Research, 5(1), 38. https://doi.org/10.5539/sar.v5n1p38

Granger, C. W. J., \& Newbold, P. (1974). Spurious regressions in econometrics. Journal of Econometrics, 2(2), 111-120. https://doi.org/10.1016/0304-4076(74)90034-7

Hatab, A. A. (2009). Performance of Egyptian Cotton Exports in International Market (pp. 225-235).

Karvy. (2009). Cotton Seasonal Report. Retrieved from http://www.karvycomtrade.com

Nerlove, M. (1958). The dynamics of supply; estimation of farmer's response to price.

Pesaran, M. H., \& Pesaran, B. (1997). Working with Microfit 4.0. Camfit Data Ltd., Cambridge.

Pesaran, M. H., Shin, Y., \& Smith, R. J. (2001). Bounds testing approaches to the analysis of level relationships. Journal of Applied Econometrics, 16(3), 289-326. https://doi.org/10.1002/jae.616

Phillips, P. C. B. (1986). Understanding spurious regressions in econometrics. Journal of Econometrics, 33(3), 311-340. https://doi.org/10.1016/0304-4076(86)90001-1

Rodríguez, X. A., \& Elasraag, Y. H. (2015). Assessing the total factor productivity of cotton production in Egypt. PLOS ONE, 10(1), 1-14. https://doi.org/10.1371/journal.pone.0116085

Soliman, I., \& Ewaida, U. (2005). Trends of public markets for Egyptian cotton. Department of Agricultural Economics, Zagazig University.

\section{Notes}

Note 1. Retrieved from https://www.cia.gov/library/publications/the-world-factbook/geos/eg.html

Note 2. Retrieved from http://unctadstat.unctad.org/EN

\section{Copyrights}

Copyright for this article is retained by the author(s), with first publication rights granted to the journal.

This is an open-access article distributed under the terms and conditions of the Creative Commons Attribution license (http://creativecommons.org/licenses/by/4.0/). 